\title{
ANALISIS IMPLEMENTASI PP NO. 12 TAHUN 2012 TENTANG INSENTIF PERLINDUNGAN LAHAN PERTANIAN PANGAN BERKELANJUTAN DI KAWASAN DANAU DUSUN BESAR KOTA BENGKULU
}

\author{
Analysis of Goverment Regulation No. 12 of 2012 Implementation on \\ Protection of Sustainable Food Agricultural Land Incentive in the \\ Dusun Besar Lake Area of Bengkulu City
}

\author{
Alimansyah'1), Yenny Sariasih'), Yuliati3) \\ 1,3Staf Pengajar Fakultas Ilmu Sosial dan Ilmu Politik, Universitas Bengkulu \\ ${ }^{2}$ Staf Pengajar Fakultas Pertanian, Universitas Bengkulu
}

\begin{abstract}
This study aims to describe how the implementation of incentives as stipulated in Government Regulation No. 12 of 2012 concerning the protection of agricultural land incentives sustainable food in the Dusun Besar Lake area of the city of Bengkulu. This research is a descriptive study with a qualitative approach. Informants determination use purposive sampling. Data collection techniques consist of observation, interviews and discussions as well as documentation. Data analysis are conducted by inductively starting from data collection, data reduction, data presentation and data verification. Based on the results of a couple of aspects studied, namely communication, resources, disposition, and bureaucratic structures, further seen from the form of the provision of incentives in the form of : agricultural infrastructure development has not been run, the financing of research and development of improved varieties of seeds and no ease of access to information and existing technology (extension), the provision of production facilities, guarantee certificate issuance of land rights on agricultural land are not sustainable food and / or rewards for high achievers existing farmers, government programs. It was concluded that the implementation of the Regulation no 12 tahun 2012 in incentives for farmers land owners in the Dusun Besar Lake area of the city of Bengkulu is not already running. While the constraints faced by the lack of regulations governing the area of land protection sustainable food. Therefore, intensive provision for sustainable food future land owners should be budgeted and city government programs through agencies or institutions concerned.
\end{abstract}

Keywords: implementation, incentive, PP, Agricultural land

\section{PENDAHULUAN}

Lahan sawah memiliki arti yang sangat penting dalam upaya mempertahankan ketahanan pangan. Namun seiring perkembangan zaman, 
pertambahan penduduk, dan tuntutan ekonomi, eksistensi lahan pangan mulai terusik. Salah satu permasalahan yang cukup serius saat ini berkaitan dengan lahan pangan adalah makin maraknya alih fungsi lahan pangan kepenggunaan lainnya (Astuti, dkk., 2011). Saat ini alih fungsi lahan pertanian pangan berkelanjutan masih menjadi salah satu ancaman terbesar bagi ketahanan pangan di Indonesia. Penetapan Undang-Undang (UU) Republik Indonesia Nomor 41 Tahun 2007 tentang Perlindungan Lahan Pertanian Pangan Berkelanjutan yang berbunyi bahwa Perlindungan Lahan Pertanian Pangan Berkelanjutan diselenggarakan dengan tujuan diantaranya yaitu: Melindungi kawasan dan lahan pertanian pangan secara berkelanjutan, menjamin tersedianya lahan pertanian pangan meningkatkan kemakmuran, kesejahteraan petani dan meningkatkan perlindungan serta pemberdayaan petani. Namun dari berbagai tujuan yang termaktub di dalam Undang-Undang ini, ternyata masih jauh dari harapan yang diinginkan atau belum efektif. Faktanya, jumlah luas lahan pertanian pangan berkelanjutan terus mengalami penurunan. Setiap tahun lebih dari sekitar 50.000 - 70.000 ha lahan pertanian pangan berkelanjutan berubah fungsi sedangkan kemampuan pemerintah dalam pencetakan sawah baru hanya sekitar 30.000 - 40.000 ha/tahun, karena keterbatasan anggaran, serta berbagai faktor sosial ekonomi, aspek kepemilikan lahan dan kendala lainnya (Jamil, dkk., 2013). Apabila hal ini terus dibiarkan berlanjut, maka ke depan Lahan Pertanian Pangan Berkelanjutan akan semakin berkurang.

Oleh sebab itu sebagai upaya untuk mempertahankan dan melindungi lahan pangan, Pemerintah mengeluarkan kebijakan turunan dari UU Nomor 41 tahun 2007 tentang Perlindungan lahan pertanian pangan berkelanjutan yaitu Peraturan Pemerintah (PP) Nomor 12 tahun 2012 tentang Insentif Perlindungan Lahan Pertanian Pangan Berkelanjutan (PLPPB). Dalam Bab I Tentang ketentuan umum, Pasal 1 ayat 3 berbunyi "Insentif adalah pemberian penghargaan kepada Petani yang mempertahankan dan tidak mengalihfungsikan Lahan Pertanian Pangan Berkelanjutan". Hal ini mengingat bahwa lahan pertanian produktif merupakan aset penting dalam pembangunan pertanian karena hal ini didasarkan atas dua hal yaitu besarnya biaya investasi yang telah dikeluarkan dalam bentuk sarana dan prasarana irigasi dan pencetakan sawah baru serta lamanya waktu yang dibutuhkan untuk membuat sawah baru hingga terbentuknya lahan sawah dengan tingkat produktivitas yang tinggi (Catur, et al., 2010).

Sedangkan tujuan pemberian insentif, perlindungan lahan pertanian pangan berkelanjutan adalah untuk: a. mendorong perwujudan Lahan Pertanian Pangan Berkelanjutan yang telah ditetapkan, b. meningkatkan upaya pengendalian alih fungsi Lahan Pertanian Pangan Berkelanjutan, c. meningkatkan pemberdayaan, pendapatan, dan kesejahteraan bagi Petani, d. memberikan kepastian hak atas tanah bagi Petani dan e. meningkatkan 
kemitraan semua pemangku kepentingan dalam rangka pemanfaatan, pengembangan, dan perlindungan Lahan Pertanian Pangan Berkelanjutan sesuai dengan tata ruang. Insentif yang akan diberikan meliputi: pengembangan infrastruktur pertanian, pembiayaan penelitian dan pengembangan benih dan varietas unggul, kemudahan dalam mengakses informasi dan teknologi, penyediaan sarana dan prasarana produksi, jaminan penerbitan sertifikat hak atas tanah pada lahan pertanian pangan berkelanjutan, dan atau penghargaan bagi petani berprestasi tinggi.

Hal ini menjadi menarik untuk diteliti, sebagaimana hasil penelitian Alimansyah (2011) yang menyatakan bahwa "Salah satu faktor yang menyebabkan alih fungsi lahan pertanian pangan berkelanjutan di kawasan Dusun Besar yaitu pemberian insentif bagi petani belum terlaksana dengan baik". Dengan demikian berdasarkan permasalahan tentang alih fungsi lahan pangan dan dikeluarkannya PP No 12 Tahun 2012 Tentang insentif PLPPB maka peneliti dalam penelitian ini memfokuskan penelitian pada Analisis Implementasi PP No.12 Tahun 2012 Tentang Insentif Perlindungan Lahan Pertanian Pangan Berkelanjutan Di Kawasan Dusun Besar Bengkulu.

Tujuan dari penelitian ini untuk mendeskripsikan proses Implementasi Kebijakan Peraturan Pemerintah (PP) Nomor 12 Tahun 2012 Tentang Insentif Perlindungan Lahan Pertanian Pangan Berkelanjutan di kawasan Dusun Besar Bengkulu dan mendeskripsikan kendala-kendala yang di hadapi oleh Pemda dalam Mengimplementasikan PP No 12 Tahun 2012 Tentang Insentif Perlindungan Lahan Pertanian Pangan Berkelanjutan Di Kawasan Dusun Besar Bengkulu.

\section{METODE PENELITIAN}

Jenis penelitian ini yaitu penelitian deskriptif dengan pendekatan kualitatif. Aspek penelitian, dalam penelitian ini yaitu: 1. Komunikasi, 2. Sumber Daya, 3. Disposisi, dan 4. Struktur Birokrasi. Teknik penentuan informan menggunakan teknik purposive sampling atau sampel bertujuan, adapun informan yang dijadikan dalam penelitian ini yaitu : Pelaksana kebijakan yaitu Sekretaris, kepala bidang/seksi dan staf di dinas pertanian, peternakan, perkebunan dan kehutanan kota Bengkulu, petani pemilik sawah, kelompok tani, kelompok tani pemakai air, kepala/sekretaris lurah dusun besar, dan dinas pertanahan kota Bengkulu. Adapaun jumlah informan dalam penelitian yang telah dilakukan yaitu sebanyak 16 orang. Berdasarkan kebutuhan akan terpenuhinya jumlah data penelitian yang dibutuhkan, sudah dirasakan cukup oleh tim peneliti.

Teknik pengumpulan data dalam penelitian ini terdiri dari: 1 . Observasi dilakukan dengan cara pemantauan secara langsung di lapangan terhadap obyek yang diteliti, dengan melakukan pencatatan, mengidentifikasi data-data yang diperoleh di lapangan. 2. Wawancara atau interview dan diskusi. 
Wawancara yaitu dengan cara berkomunikasi secara langsung dengan informan penelitian, sesuai dengan fokus penelitian. 3. Dokumentasi dilakukan untuk menambah data yang dibutuhkan.

Analisis data dalam penelitian kualitatif secara teknis dilaksankan secara induktif yaitu analisa yang dimulai dari pengumpulan data, reduksi data, penyajian data dan verifikasi data. Adapun analisis data dalam penelitian ini yaitu sebagai berikut: 1. Pengumpulan data berupa catatan di lapangan, gambaran, hasil diskusi dan lainnya diperiksa kembali, diatur dan kemudian diurutkan, 2. Reduksi data, hasil penelitian dari lapangan sebagai bahan mentah dirangkum direduksi kemudian disusun supaya lebih sistematis, yang difokuskan pada pokok-pokok dari hasil penelitian yang disusun secara sitematis untuk mempermudah penelitian didalam mencari kembali data yang diperoleh apabila diperlukan kembali. Dari data-data tersebut peneliti membuat catatan atau rangkaian yang disusun secara sitematis, 3. Sajian data, dapat membantu peneliti untuk melihat gambaran keseluruhan atau bagianbagian tertentu dari hasil penelitian, 4. Verifikasi data, data-data yang diperoleh dari hasil wawancara, observasi dan dokumentasi. Kemudian peneliti mencari makna dari hasil penelitian atau hasil yang dikumpulkan. Selanjutnya peneliti berusaha untuk membuat kesimpulan.

\section{HASIL DAN PEMBAHASAN}

Penelitian ini mengambil 16 orang yang menjadi informan, 3 orang dari dinas pertanian, peternakan, perkebunan dan kehutanan kota Bengkulu, sebagai implementor kebijakan, 2 orang dari kelurahan Dusun Besar, 1 orang dari dinas pertanahan, 2 orang dari kelompok tani, 2 orang perkumpulan petani pemakai air dan 6 orang dari petani dan buruh tani, sebagaimana terdapat pada Tabel 1.

Dari ke 16 orang informan terdapat 12 informan berjenis kelamin lakilaki dan 4 orang perempuan. Berdasarkan klasifikasi umur, umur kurang dari 30 tahun 1 orang, umur 30-40 tahun sebanyak 3 orang, umur 40-50 tahun sebanyak 6 orang dan umur 50 tahun keatas yaitu sebanyak 6 orang. Dari ke 16 orang informan yang diambil dalam penelitian ini, peneliti menganggap informan yang ada sudah cukup representatif dan proporsional untuk mendapatkan data sesuai tujuan penelitian.

Berdasarkan hasil penelitian tentang Implementasi Kebijakan Peraturan Pemerintah (PP) Nomor 12 Tahun 2012 Tentang Insentif Perlindungan Lahan Pertanian Pangan Berkelanjutan di Kawasan Dusun Besar kota Bengkulu, dari berberapa Aspek yang diteliti dalam penelitian ini yaitu Komunikasi, Sumber Daya, Disposisi, dan Struktur Birokrasi. Maka hasil yang dicapai adalah sebagai berikut: 
Tabel 1. Informan Penelitian

\begin{tabular}{|c|c|c|c|}
\hline No & Nama & Instansi/Jabatan & Umur \\
\hline 1 & Saryono & Dinas Pertanian/Sekretaris Dinas & 47 Tahun \\
\hline 2 & Susti Mediana & $\begin{array}{l}\text { Dinas Pertanian/Kasi Pengelolaan } \\
\text { Lahan dan Air }\end{array}$ & 42 Tahun \\
\hline 3 & Zuardi & Dinas Pertanian/PPK & 38 Tahun \\
\hline 4 & Parlan & $\begin{array}{l}\text { Bidang Layanan Informasi Badan } \\
\text { Pertanahan kota Bengkulu }\end{array}$ & 48 Tahun \\
\hline 5 & Rustam Efendi & Lurah Dusun Besar & 54 Tahun \\
\hline 6 & Gunawan & Sekretaris Lurah Dusun Besar & 53 Tahun \\
\hline 7 & Ibnu Hafaz & Ketua KP2A Temetung & 48 Tahun \\
\hline 8 & Musa Amrun & Ketua KP2A Talang Lembak & 53 Tahun \\
\hline 9 & Pikri HZ & Sekretaris kelompok tani Sekotong & 43 Tahun \\
\hline 10 & Muhamad SM & Anggota Kelompok tani sekotong & 36 Tahun \\
\hline 11 & Rosdianah & Petani & 54 Tahun \\
\hline 12 & Ramdani & Petani & 48 Tahun \\
\hline 13 & Supardi & Petani & 51 Tahun \\
\hline 14 & Rosmala Dewi & Petani & 33 Tahun \\
\hline 15 & Siswandi & Petani & 51 Tahun \\
\hline 16 & Siti Masita & Petani & 24 Tahun \\
\hline
\end{tabular}

1. Komunikasi

Hasil penelitian aspek komunikasi didapatkan bahwa implementor dari tiga orang informan yang diwawancarai mengetahui peraturan pemerintah (PP) Nomor 12 Tahun 2012 Tentang Insentif Perlindungan Lahan Pertanian Pangan Berkelanjutan, mengetahui apa yang harus dikerjakan dalam mengimplementasikan pemberian insentif bagi petani di kawasan dusun besar kota Bengkulu, selain itu implementor mengetahui tujuan dan kelompok sasaran (target group) yang menjadi sasaran kebijakan pemberian insentif ini.

Adapun komunikasi dalam pelaksanaan kebijakan Peraturan Pemerintah (PP) Nomor 12 Tahun 2012 Tentang Insentif Perlindungan Lahan Pertanian Pangan Berkelanjutan seperti sosialisasi kepada petani pemilik sawah atau lahan pangan berkelanjutan, baik melalui sosialisasi aturan dan penyuluhan yang dilakukan oleh penyuluh pertanian serta penyaluran atau pelaksanaan insentif bagi petani oleh pemerintah kota belum berjalan.

2. Sumber Daya

Berdasarkan hasil penelitian dari aspek sumber daya dalam pelaksanaan kebijakan Peraturan Pemerintah (PP) Nomor 12 Tahun 2012 tentang insentif perlindungan lahan pertanian pangan berkelanjutan ini pertama sumber daya manusia (SDM), bahwa SDM di Dinas Pertanian, peternakan, perkebunan dan kehutanan Kota Bengkulu sudah cukup dan 
mumpuni baik secara kuantitas dan kualitas. Kedua berkaitan dengan sumber daya kapital dalam hal ini anggaran/finansial, berdasarkan hasil penelitian pemerintah kota secara khusus belum menganggarkan insentif bagi petani dikawasan dusun besar pada tahun 2014 dan baru akan ajukan anggaran beberapa tahun kedepan, sehingga anggaran secara khusus dari dinas pertanian kota sebagai insentif kepada petani di kawasan dusun besar selama ini belum ada. Kalaupun ada berupa subsidi seperti pupuk, pemberian mesin giling padi dan lain-lain bukan dari pelaksanaan dari PP ini, namun merupakan program yang ada dibidang dinas pertanian yang sama dengan aturan yang ada di PP tersebut, selain itu program yang sudah berjalan selama ini merupakan pelaksanaan kegiatan yang merupakan bantuan program yang diberikan oleh pemerintah pusat atau pemerintah provinsi yaitu penghargaan bagi petani teladan kota.

\section{Disposisi}

Berdasarkan hasil penelitian aspek Disposisi dari hasil penelitian berupa watak dan karakteristik yang dimiliki oleh para implementor seperti komitmen, kejujuran dan sifat demokratis belum bisa dilihat disposinya, hal ini dikarenakan pada tahun 2014 dinas pertanian, peternakan, perkebunan dan kehutanan kota Bengkulu belum melaksanakan peraturan kebijakan Peraturan Pemerintah (PP) Nomor 12 Tahun 2012 Tentang Insentif Perlindungan Lahan Pertanian Pangan Berkelanjutan di kawasan Dusun Besar. Disposisi yang sudah berjalan selama ini merupakan pelaksanaan program yang dilakukan oleh pemerintah atau perpanjangan pemerintah melalui pemerintah provinsi dan kabupaten/kota.

\section{Struktur Birokrasi}

Berdasarkan hasil penelitian yang dilakukan bahwa struktur organisasi yang diberikan kewenangan untuk menjalankan Peraturan Pemerintah (PP) Nomor 12 Tahun 2012 Tentang Insentif Perlindungan Lahan Pertanian Pangan Berkelanjutan di kawasan Dusun Besar ini tidak dibuat struktur ataupun tim khusus yang menangani pelaksanaannya tahun 2014, namun untuk penugasan kewenangan pemberian insentif atau subsidi selama ini langsung disesuaikan dengan struktur birokrasi yang ada di dinas pertanian, peternakan dan kehutanan Kota Bengkulu seperti insentif yang berkaitan dengan sarana dan prasarana langsung dikerjakan oleh bidang sarana dan prasarana yaitu pengadaan mesin giling padi, bantuan pupuk, pestisida langsung dibawah bidang yang sesuai dengan bidang yang ada di Dinas Pertanian, Peternakan Perkebunan dan Kehutanan Kota Bengkulu.

Implementasi kebijakan Peraturan Pemerintah (PP) Nomor 12 Tahun 2012 Tentang Insentif Perlindungan Lahan Pertanian Pangan Berkelanjutan dilaksanakan berjenjang oleh pemerintah pusat, provinsi dan kabupaten/kota. 
Pembagian pelaksanaan pemberian insentif disesuaikan dengan luas lahan sawah yang ada, lahan sawah beririgasi teknis lebih dari 3000 ha yang berada dalam satu provinsi atau lintas provinsi pemberian instensifnya dilaksanakan oleh pemerintah pusat, luas lahan yang terdiri dari 3000 ha yang berada dalam kabupaten/kota atau lintas kabupaten/kota dalam satu provinsi pemberian insentifnya dilaksanakan oleh pemerintah provinsi dan luas lahan sawah beririgasi teknis kurang dari 1000 ha yang berada di dalam kabupaten/kota, maka pemberian insentifnya dilakukan oleh pemerintah kabupaten/kota, maka berkaitan dengan pemberian insentif bagi petani pemilik lahan sawah di kawasan dusun besar adalah kewenangan pemerintah kota melalui dinas yang terkait.

Kawasan Danau Dusun Besar merupakan kawasan lahan sawah beririgasi yang keberadaannya sudah ada turun temurun sejak dahulu, puluhan bahkan ratusan tahun yang lalu. Lahan sawah beririgasi dikawasan dusun besar merupakan satu kesatuan dari kawasan Danau Dusun Besar atau Danau Dendam Tak Sudah yang merupakan sumber mata air persawahan tersebut. Dalam penataan ruang seperti pada Peraturan Daerah (PERDA) Rencana Tata Ruang Wilayah (RTRW) nomor 1 tahun 1995 dan PERDA RTRW nomor 14 tahun 2012, menyatakan bahwa kawasan dusun besar merupakan kawasan yang diperuntukkan sebagai kawasan budi daya pertanian berupa sawah, hal ini sesuai dengan kondisi lahan atau tipologi lahan pertanian pangan berkelanjutan yaitu: kesuburan tanah, luas tanam, irigasi, tingkat fragmentasi lahan, dan produktivitas usaha tani, lokasi, kolektivitas usaha pertanian, dan/atau praktik usaha tani ramah lingkungan.

Sebagai kebijakan pemerintah untuk melindungi lahan sawah dari ancaman alih fungsi lahan pangan berkelanjutan di Indonesia maka pada tahun 2009 di-undangkanlah Undang-Undang (UU) nomor 41 tahun 2007 tentang perlindungan lahan pertanian pangan berkelanjutan. Dengan adanya aturan ini diharapkan dapat mencegah alih fungsi dan dapat melindungi lahan pangan berkelanjutan di Indonesia, namun seiring dengan waktu ternyata alih fungsi lahan pangan berkelanjutan terus saja terjadi bahkan laju alih fungsi lahan pertanian terutama sawah tidak terkontrol dan bahkan mengalahkan program pemerintah dalam kemampuan untuk mencetak lahan sawah yang baru.

Sebagai usaha dari bagian perlindungan yang dapat memberikan harapan dalam mengurangi laju alih fungsi lahan pangan yang semakin tidak terkontrol maka sebagai aturan yang mengatur lebih teknis, maka dikeluarkanlah Peraturan Pemerintah (PP) Nomor 12 Tahun 2012 Tentang Insentif Perlindungan Lahan Pertanian Pangan Berkelanjutan. Pemberian Insentif bagi petani pemilik lahan sawah merupakan perangkat atau upaya untuk memberikan imbalan terhadap pelaksanaan kegiatan atau program yang sejalan dengan tata ruang yang dilakukan oleh negara. 
Keberhasilan pembangunan suatu negara akan sangat dipengaruhi oleh panataan ruang yang ada, salah satu bagian dari penataan ruang yaitu bagaimana pengendalian ruang bisa berjalan dengan baik. Menurut Kodoatie dan Sjarief (2010), salah satu faktor pengendali pemanfaatan ruang dapat dilakukan melalui : Pemberian Insentif dan Disinsentif sehingga hal ini relevan dengan Peraturan Pemerintah Nomor 12 Tahun 2012 Tentang Insentif Perlindungan Lahan Pertanian Pangan Berkelanjutan, didalamnya disebutkan bahwa insentif yang akan diberikan meliputi: pengembangan infrastruktur pertanian, pembiayaan penelitian dan pengembangan benih dan varietas unggul, kemudahan dalam mengakses informasi dan teknologi, penyediaan sarana dan prasarana produksi, jaminan penerbitan sertifikat hak atas tanah pada lahan pertanian pangan berkelanjutan; dan/atau penghargaan bagi petani berprestasi tinggi.

Berdasarkan pemberian insentif yang akan dilaksanakan dikawasan dusun besar dapat diketahui pelaksanaan pemberian intensif melalui implementor yang seharusnya melaksanakan Peraturan Pemerintah Nomor 12 Tahun 2012 Tentang Insentif Perlindungan Lahan Pertanian Pangan Berkelanjutan yaitu pemerintah Kota Bengkulu melalui dinas pertanian, peternakan, perkebunan dan kehutanan. Keberhasilan implementasi kebijakan akan ditentukan oleh banyak variabel/aktor/aspek, dan masing masing aspek tersebut saling berhubungan antara satu sama lainnya (Subarsono, 2005).Dari beberapa faktor yang menjadi aspek yang diteliti dalam penelitian ini yaitu Komunikasi, Sumber Daya, Disposisi, dan Struktur Birokrasi.

Berdasarkan aspek komunikasi bahwa implementor mengetahui tujuan pemberian insentif dan kelompok sasaran (target group) yang menjadi sasaran kebijakan pemberian insentif. Namun pemahaman tentang tujuan, langkah apa yang harus dilakukan dan target sasaran siapa belum disertai dengan pelaksanaan yang harus dilakukan seperti sosialisasi, baik melalui sosialisasi aturan dan penyuluhan yang dilakukan oleh penyuluh pertanian serta penyaluran atau pelaksanaan insentif bagi petani oleh pemerintah kota belum berjalan. Hal ini dikarenakan belum adanya peraturan daerah yang mengatur tentang perlindungan lahan pangan berkelanjutan yang didalamnya diatur tentang pemberian insentif bagi petani serta prioritas pemerintah kota yang menjadikan sektor pertanian bukan menjadi prioritas pemerintah kota saat ini, sehingga hal ini merugikan bagi petani pemilik sawah yang seharusnya mendapatkan pemberian insentif atas kepemilikan lahan sawah yang dimiliki sesuai dengan Undang-Undang dan peraturan pemerintah dalam melindungi petani dan lahan sawah atau pangan.

Berdasarkan aspek Sumber daya, pertama sumber daya manusia (SDM), bahwa SDM sebagai implementor sudah cukup dan mumpuni baik secara kuantitas dan kualitas. Namun hal ini tidak didukung dengan sumber daya finansial dalam hal ini anggaran pemberian insentif bagi petani pemilik 
sawah, pemerintah kota secara khusus belum menganggarkan insentif bagi petani di kawasan dusun besar pada tahun 2014 dan baru akan mengajukan anggaran beberapa tahun ke depan, sehingga anggaran secara khusus dari dinas pertanian, peternakan, perkebunan dan kehutanan kota sebagai insentif kepada petani di kawasan dusun besar selama ini belum ada. Berdasarkan hasil penelitian bahwa sumber daya manusia implementor cukup dan mumpuni namun hal ini tidak akan berjalan efektif tanpa adanya penganggaran yang dianggarkan untuk pemberian insentif bagi petani pemilik sawah yang merupakan kewenangan pemerintah kota.

Berdasarkan aspek Disposisi berupa watak dan karakteristik yang dimiliki oleh para implementor seperti komitmen, kejujuran dan sifat demokratis belum bisa dilihat disposisinya, hal ini dikarenakan pada tahun 2014 dinas pertanian, peternakan, perkebunan dan kehutanan kota Bengkulu belum melaksanakan peraturan kebijakan Peraturan Pemerintah (PP) Nomor 12 Tahun 2012 Tentang Insentif Perlindungan Lahan Pertanian Pangan Berkelanjutan di kawasan Dusun Besar. Namun belum dilaksanakannya pemberian insentif bagi petani oleh pemerintah kota memberi ruang tentang adanya perbedaan perspektif antara pembuat kebijakan/pemerintah pusat dengan pemerintah kota, pemahaman yang berbeda terutama oleh pemerintah kota menyebabkan kebijakan pemberian insentif bagi petani pemilik sawah menjadi tidak efektif. Adapun disposisi yang sudah berjalan baik selama ini merupakan pelaksanaan program yang dilakukan oleh pemerintah atau perpanjangan pemerintah melalui pemerintah provinsi dan kabupaten/kota.

Aspek struktur organisasi, yaitu struktur yang diberikan kewenangan untuk menjalankan Peraturan Pemerintah (PP) Nomor 12 Tahun 2012 Tentang Pemberian Insentif Perlindungan Lahan Pertanian Pangan Berkelanjutan, belum dibuat strukturnya ataupun tim khusus yang menangani pelaksanaan pada tahun 2014. Hal ini akan menyulitkan implementasi pemberian insentif apabila tidak adanya struktur khusus yang menangani hal ini, walaupun selama ini untuk penugasan kewenangan pemberian bantuan atau program pada petani disesuaikan dengan struktur birokrasi yang ada di dinas pertanian, peternakan, perkebunan dan kehutanan kota Bengkulu maka pelaksanaannya akan kurang berjalan efektif.

Berdasarkan aspek-aspek penelitian dari pelaksana (implementor kebijakan) maka pemberian insentif yang diberikan oleh pelaksana kebijakan berupa: pengembangan infrastruktur pertanian, belum berjalan, pembiayaan penelitian dan pengembangan benih dan varietas unggul belum ada, kemudahan dalam mengakses informasi dan teknologi sudah ada, penyediaan sarana dan prasarana produksi, jaminan penerbitan sertifikat hak atas tanah pada lahan pertanian pangan berkelanjutan belum ada dan/atau penghargaan bagi petani berprestasi tinggi sudah ada. 
Dari pemberian insentif yang sudah berjalan atau ada selama ini bukanlah bagian dari pelaksanaan Peraturan Pemerintah (PP) Nomor 12 Tahun 2012 Tentang Insentif Perlindungan Lahan Pertanian Pangan Berkelanjutan oleh pemerintah Kota Bengkulu, namun merupakan bagian dari program pemerintah pusat seperti pemberian penghargaan berupa sertifikat dan pelatihan bagi petani teladan tingkat nasional dari Bengkulu bapak Ibnu Hafaz dan pemberian informasi melalui penyuluh pertanian.

Adapun kendala-kendala yang menghambat pelaksanaan pemberian insentif bagi petani pemilik lahan sawah yaitu belum adanya peraturan daerah yang mengatur tentang perlindungan lahan pangan berkelanjutan pertanian. Selain itu pertanian dalam hal ini sawah tidak menjadi prioritas bagi pemerintah kota, oleh sebab itu penganggaran untuk pemberian insentif bagi petani pemilik sawah di kawasan dusun besar belum dilaksanakan oleh pemerintah Kota Bengkulu melalui dinas terkait yaitu Dinas Pertanian, Peternakan, Perkebunan dan Kehutanan Kota Bengkulu.

\section{SIMPULAN}

Berdasarkan hasil penelitian dari beberapa aspek yang diteliti yaitu komunikasi, sumber daya, disposisi, dan struktur birokrasi yang ada dan dilakukan oleh implementor, serta pelaksanaan pemberian insentif berupa: pengembangan infrastruktur pertanian belum berjalan, pembiayaan penelitian dan pengembangan benih dan varietas unggul belum ada, kemudahan dalam mengakses informasi dan teknologi sudah ada (penyuluh), penyediaan sarana dan prasarana produksi, jaminan penerbitan sertifikat hak atas tanah pada lahan pertanian pangan berkelanjutan belum ada dan/atau penghargaan bagi petani berprestasi tinggi sudah ada, program pemerintah.

Maka dari hasil penelitian ini dapat disimpulkan bahwa implementasi Peraturan Pemerintah (PP) Nomor 12 Tahun 2012 Tentang Insentif Perlindungan Lahan Pertanian Pangan Berkelanjutan di kawasan Dusun Besar Kota Bengkulu belum berjalan. Hal ini terkendala dengan belum adanya peraturan daerah yang mengatur tentang perlindungan lahan pangan berkelanjutan. Selain itu sektor pertanian tidak menjadi prioritas bagi pemerintah Kota Bengkulu, oleh sebab itu penganggaran untuk pemberian insentif bagi petani pemilik sawah di kawasan dusun besar belum dilaksanakan oleh pemerintah Kota Bengkulu melalui dinas terkait yaitu Dinas Pertanian, Peternakan, Perkebunan dan Kehutanan. 


\section{DAFTAR PUSTAKA}

Alimansyah. 2011. Penyimpangan Pemanfaatan Ruang (Studi Kasus Alih Fungsi Lahan Sawah Beririgasi Danau Dusun Besar Kota Bengkulu). Tesis. Universitas Gadjah Mada. Yogyakarta.

Astuti, UP., Wibawa, W., Ishak A. 2011. Faktor yang Mempengaruhi Alih Fungsi Lahan Pangan Menjadi Kelapa Sawit di Bengkulu: Kasus Petani Di Desa Kungkai Baru. Prosiding Seminar Nasional Budidaya Pertanian. Urgensi dan Strategi Pengendalian Alih Fungsi Lahan Pertanian. Bengkulu 7 Juli 2011.ISBN 978-602-19247-0-9.

Catur TB, Purwanto J, Uchyani RF dan Susi WA. 2010. Dampak Alih Fungsi Lahan Pertanian ke Sektor Non Pertanian terhadap Ketersediaan Beras di Kabupaten Klaten Provinsi Jawa Tengah. J.Caraka Tani.Vol. 25 (1):38-42.

Jamil, A., Maswar, Husnain. 2013. Pengelolaan Sumberdaya Tanah Ramah Lingkungan Mendukung Pembangunan Pertanian Berkelanjutan. Prosiding Seminar Nasional Balai Pengkajian Teknologi Pertanian.Bengkulu. Hal:427-437.

Kodoatie, Robert J dan Sjarief, Roestam. 2010. Tata Ruang Air. Andi. Yogyakarta. Hal. 450.

Peraturan Pemerintah Nomor 12 Tahun 2012 Tentang Insentif Perlindungan Lahan Pertanian Pangan Berkelanjutan.

Subarsono, A.G. 2005. Analisis Kebijakan Publik: Konsep, Teori, dan Aplikasi. Pustaka Pelajar. Yogyakarta.

Undang-Undang Republik Indonesia Nomor 41 Tahun 2007 Tentang Perlindungan Lahan Pertanian Pangan Berkelanjutan. 